\title{
GAMBARAN KEKUATAN KELUARGA PADA ETNIS JAWA: STUDI PADA KASUS TUNGGAL
}

\author{
Widya Risnawaty \\ Fakultas Psikologi, Universitas Tarumanagara Jakarta \\ Email: widyar@fpsi.untar.ac.id
}

\begin{abstract}
ABSTRAK
Family Strengths Framework mengulas lebih banyak tentang kekuatan positif yang dimiliki oleh keluarga dan anggota keluarga di dalamnya, sehingga dapat bertahan dalam menghadapi tantangan dan kesulitan hidup. Penelitian ini merupakan penelitian kualitatif dengan desain studi kasus tunggal yang bertujuan untuk menggali perspektif partisipan terhadap kekuatan keluarga dengan latar belakang budaya Jawa. Partisipan dipilih karena merepresentasikan keluarga harmonis yang dilatarbelakangi oleh budaya Jawa. Penelitian dilakukan di Yogyakarta. Adapun teknik pengumpulan data yang digunakan adalah wawancara mendalam. Hasil penelitian menunjukkan adanya satu temuan khas yaitu konsep "Iso lan Gelem", atau dalam bahasa Indonesia dapat diartikan "Bisa dan Mau". Konsep "Iso lan Gelem" ini merupakan kekuatan positif keluarga dari partisipan, yang selama ini digunakan oleh partisipan sebagai acuan dalam hidup berkeluarga. Konsep "Iso lan Gelem" yang dikemukakan oleh partisipan memiliki kesepadanan makna dengan 5 dimensi dari Family Strengths Framework, yaitu: (a) komunikasi positif, (b) apresiai dan afeksi, (c) kemampuan untuk mengatasi stres dan krisis secara efektif, (d) kesejahteraan Spiritual, dan (e) komitmen. Sedangkan 1 dimensi dalam Family Strengths Framework yang tidak ditemukan pada data dari partisipan adalah dimensi "menikmati waktu bersama".
\end{abstract}

Kata kunci: Family Strengths, kekuatan keluarga, etnis Jawa.

\section{PENDAHULUAN}

Menjalani dinamika kehidupan berkeluarga umumnya tak dapat dilepaskan dari konflik dan tantangan. Ada keluarga yang berhasil mengatasi konflik dan menghadapi tantangan, namun ada pula keluarga yang gagal melakukan keduanya. Pada beberapa penelitian lebih menyoroti difsungsi keluarga yang digambarkan dalam berbagai problem keluarga, antara lain: (a) kurangnya perhatian dan kasih sayang, kekerasan dalam rumah tangga, hambatan untuk mengekspresikan emosi secara terbuka (Compton, 2005; Conoley \& Conoley, 2009); (b) kenakalan yang dilakukan oleh anak, pertengkaran antara anggota keluarga, perselingkuhan bahkan sampai pada perceraian (Rice, 1999); (c) bermacam stresor seperti faktor kemiskinan dan perselisihan hingga mengakibatkan depresi (Ahmed, 2005).

Family strengths framework memiliki paradigma yang berbeda dalam memandang keluarga. Family strengths framework lebih tertarik pada hal-hal positif yang dimiliki oleh keluarga sehingga mampu bertahan dalam berbagai masalah ataupun krisis yang dihadapi dalam keluarga. Pada dasarnya, model ini tidak mengabaikan masalah ataupun kesulitan yang dialami keluarga. Namun lebih memfokuskan pada kekuatan yang dimiliki keluarga untuk membangun keluarga yang lebih kuat dalam menghadapi tantangan (DeGenova, Stinnet \& Stinnet, 2011; Olson \& DeFrain, 2006).

Konsep tentang family strengths pertama kali diteliti oleh Herbert Otto pada tahun 1962 (dalam Important notes about family strengths from Olson, 2006). Otto mendefinisikan family strengths sebagai karakteristik secara sosial dan psikologis yang menciptakan rasa positif terhadap identitas keluarga, meningkatkan kepuasan dalam berinteraksi di antara anggota keluarga, dan mendorong perkembangan potensi masing-masing anggota keluarga (Wheeler, 2008). Pada perkembangan selanjutnya, terdapat peneliti-peneliti lain yang melakukan penelitian di ranah yang sama, antara lain Nick Stinnett dan John DeFrain (dalam DeGenova, Stinnet \& Stinnet, 2011). 
Penelitian ini mengacu pada teori family strengths framework (Olson \& DeFrain, 2006; Asay \& DeFrain, 2012), yang di dalamnya terdapat 6 dimensi kekuatan keluarga, antara lain: (a) apresiasi dan afeksi, dengan indikator saling menjaga, persahabatan, respek terhadap individu, membawa keluarga dalam kondisi yang menyenangkan, humor; (b) komitmen dengan indikator kepercayaan, kejujuran, dapat diandalkan, kesetiaan dan mau berbagi; (c) komunikasi positif, dengan indikator saling berbagi perasaan, memberikan pujian, menghindari saling menyalahkan, dapat saling berkompromi, terbuka terhadap ketidaksetujuan; (d) kesejahteraan spiritual, dengan indikator adanya harapan, keyakinan, pengorbanan, berbagi nilai etis, kesatuan dalam kemanusiaan; (e) menikmati waktu bersama, dengan indikator mengutamakan kualitas saat pertemuan bersama, kualitas relasi yang baik memerlukan kuantitas waktu pertemuan, saling menikmati saat kebersamaan, berbagi saat-saat menyenangkan; (f) kemampuan untuk mengatasi stres dan krisis secara efektif, dengan indikator adanya kemampuan beradaptasi, melihat krisis sebagai tantangan dan kesempatan, bertumbuh dalam krisis dan terbuka terhadap perubahan, dan menjadi resilien.

Penelitian mengenai family strengths atau kekuatan keluarga, telah banyak dilakukan di berbagai negara pada berbagai suku bangsa. John DeFrain dibantu oleh kolega-koleganya meneliti tentang family strengths dari berbagai persepektif di 18 negara, antara lain: Afrika Selatan, Bostwana, Kenya, Somali, Israel, Oman, China, India, Korea, Australia, Selandia Baru, Kanada, Amerika, Meksiko, Brasil, Rusia, Yunani dan Rumania (dalam DeFrain \& Asay, 2012). Family strengths atau kekuatan keluarga merupakan kualitas-kualitas positif yang menjadi fondasi atau kekuatan bagi suatu keluarga dalam menghadapi segala stimulus lingkungan dan tantangan kehidupan (Olson \& DeFrain, 2006).

Berdasarkan kajian yang dilakukan baik oleh DeFrain, Asay (dalam DeFrain \& Asay, 2012), maupun oleh Olson (dalam Important notes about family strengths from Olson, 2006), ditemukan bahwa terbentuknya family strengths sangat dipengaruhi oleh faktor budaya yang melatarbelakangi kehidupan keluarga. Oleh karena itu, kekuatan keluarga yang ada pada setiap keluarga dari suku bangsa, kewarganegaraan atau ras yang berbeda pasti akan berbeda pula. Setiap negara, suku bangsa dan ras memiliki kekhasan masing-masing dan tidak dapat digeneralisasikan. Oleh sebab itu, gerakan family strengths framework melakukan penelitian secara internasional yang merupakan studi lintas budaya.

Merujuk pada pernyataan tersebut, penelitian ini menggunakan kajian yang sama namun diterapkan dalam setting penelitian yang berbeda. Penelitian ini bertujuan untuk mengetahui family strengths yang terbentuk pada keluarga etnis Jawa. Etnis Jawa dipilih karena sudah banyak penelitian yang berbasis psikologi yang meneliti tentang budaya Jawa, namun belum ada yang secara spesifik mengukur family strengths atau kekuatan keluarga pada keluarga dengan latar belakang budaya Jawa. Diharapkan dari penelitian awal ini dapat menemukan kearifan lokal yang terinternalisasi dalam nilai-nilai keluarga sebagai fondasi untuk membentuk kekuatan keluarga.

Sebagai studi awal, dalam penelitian ini akan digunakan studi kasus tunggal dimana partisipan adalah seorang individu yang telah berkeluarga dan telah menjalani pernikahannya selama 32 tahun. Selain itu, partisipan dinilai oleh lingkungannya sebagai individu yang berpengetahuan luas, sangat menguasai dan paham tentang budaya Jawa. Partisipan juga dikenal sebagai pemandu acara dalam acara pernikahan tradisional Jawa. Ia kerap diminta bantuan dan jasanya untuk menjadi pemandu acara pernikahan tradisional Jawa. Keluarga yang dibangunnya pun dikenal sebagai keluarga yang harmonis. Oleh karena itu ia kerap diperbantukan juga oleh pihak gereja Katolik untuk membantu para pasangan suami istri yang memerlukan pendampingan keluarga. 


\section{METODE PENELITIAN}

Jenis penelitian yang digunakan dalam penelitian ini adalah penelitian kualitatif dengan bentuk studi kasus tunggal. Teknik pengumpulan data yang digunakan adalah wawancara mendalam.Alat ukur utama yang akan digunakan dalam penelitian ini adalah pedoman wawancara yang dikembangkan sendiri oleh peneliti dengan mengacu pada konsep teori Family strengths framework. Data akan ditampilkan dalam bentuk naratif, yaitu memaparkan atau menceritakan ulang isi jawaban partisipan berdasarkan perspektif dan intepretasi personal dari partisipan.

Adapun karakteristik partisipan: (a) memiliki usia pernikahan 32 tahun (telah melampaui usia pernikahan 20 tahun); (b) masih terikat dalam pernikahan resmi hingga saat proses wawancara berlangsung; (c) memiliki pemahaman yang kuat tentang adat budaya Jawa; (d) memiliki keluarga yang dikenal harmonis. Sedangkan area domilisi dipilih kota Yogyakarta karena sebagai Daerah Istimewa, Yogyakarta dipandang masih cukup representatif menghadirkan nilai-nilai budaya Jawa sehingga data yang diperoleh diharapkan dapat mencerminkan kearifan lokal budaya Jawa.

Sebagai langkah awal, telah disusun panduan wawancara yang bersifat terbuka. Dalam arti, sangat dimungkinkan untuk menambah dan mengembangkan pertanyaan-pertanyaan baru yang relevan dan sesuai dengan target yang ingin dicapai. Wawancara dilakukan sebanyak 3 kali dengan durasi 60 - 90 menit untuk setiap wawancara. Kemudian selanjutnya dilakukan pengolahan dan analisis data. Teknis analisis data yang digunakan adalah pattern matching atau penjodohan pola, yaitu dengan membandingkan pola temuan dari data empiris dengan pola yang diacu secara teoretis. Tahap terakhir menuangkan dalam paparan pembahasan dan simpulan.

\section{HASIL DAN PEMBAHASAN}

Partisipan seorang laki-laki berusia 57 tahun dan telah melampaui 32 tahun usia pernikahan. Partisipan berinisial An dan istrinya berinisial H. Mereka berdua berasal dari Yogyakarta, lahir dan dibesarkan di Yogyakarta. Keduanya beragama Katolik sejak lahir. An merupakan anak ke 1 dari 5 bersaudara. Sejak lahir hingga ia duduk di bangku SMP, ia lebih banyak menghabiskan waktu di Wonosari, salah satu kecamatan di Yogyakarta. Kemudian, memasuki tahap pendidikan SMA, ia dititipkan pada saudara, dalam istilah bahasa Jawa disebut "ngenger" dengan arti dititipkan untuk bekerja dan sekaligus dididik agar menjadi orang sukses. An dititipkan kepada salah satu saudara Ibunya yang ia panggil dengan sebutan Pak De (bapak Gede yang artinya saudara tua kakak dari Ibu/ayah). Alasan orangtua An menitipkan An pada Pak De adalah bahwa Pak De ini telah mencapai kesuksesan yang mengagumkan.

Setelah menikah An dan istrinya dikaruniai 2 orang anak perempuan. Pada tahun 2014 yang lalu An telah menikahkan anak pertamanya dan telah dianugerahi seorang cucu perempuan. Sedangkan anak keduanya telah lulus kuliah dan saat ini bekerja di Yogyakarta. Sejak anak-anak lahir, An bersama istri telah membiasakan anak-anak mereka untuk berbahasa Jawa dan dididik berdasarkan tata krama budaya Jawa. An sangat menjunjung tinggi filosofi budaya Jawa. Nilai-nilai budaya Jawa selalu mewarnai setiap pikiran, tindakan dan rasa dalam berperilaku.

\section{Persepsi Tentang Keluarga Tangguh dan Harmonis}

An memandang keluarga tangguh sebagai keluarga yang harmonis. Menurut An, keluarga yang tangguh adalah keluarga yang kuat, mampu untuk bertahan dalam menghadapi masalah. Keluarga yang mampu mengatasi perbedaan dengan mampu bersikap menerima apa adanya segala kekurangan anggota keluarga. Seperti yang paparkan dalam kutipan dari An sebagai berikut: "harmonis...keluarga harmonis...angel mbak...piye yo....tapi mungkin yang kita anukan itu ya kita terima adanya, itulah... dengan dia, kekurangannya dia sudah itu saya terima gini, dan dia juga, kekurangan saya dia bisa menerima. Semua itu sudah kita anukan gini, dan kita sudah mau menerima, puas apa adanya dengan kita. keluarga 
tangguh...ya keluarga yang kuat, tidak bercerai meskipun masalah datang bertubi-tubi. Tidak ada tanpa... tidak ada tanpa pertengkaran saja, karena itu sebagai tanda petik ya, tidak ada tanpa perbedaan pendapat, tidak ada, mesti ada... hanya tinggal bagaimana mengatasinya, itu"

Pada kutipan tersebut, An memaknai keluarga yang tangguh sama arti dengan keluarga harmonis. Di dalam kutipan tersebut, An menekankan adanya komitmen antar anggota keluarga, yaitu: kemauan untuk saling menerima apa adanya terutama kekurangan yang dimiliki masing-masing anggota keluarga, kemauan untuk menghadapi masalah dan perbedaan pendapat secara bersamasama.

\section{Kekuatan Positif Keluarga Jawa dari perspektif partisipan}

Terdapat beberapa kekuatan positif yang digunakan oleh An dalam mempertahankan kehidupan berkeluarganya. An mengemukakan konsep "Iso lan Gelem" yang dalam bahasa Indonesia dapat diartikan "Bisa dan Mau" merupakan hasil refleksi bertahun-tahun An terhadap pola interaksi hidup berkeluarga yang sudah dijalaninya. Konsep "Iso lan Gelem" merupakan kekuatan positif yang dijadikan pedoman oleh An untuk mempertahankan dan memperteguh hidup berkeluarga.

Secara spesifik dapat dijelaskan sebagai berikut: (a) "Iso" dapat dimaknakan sebagai kemampuan yang dimiliki oleh individu; (b) "Gelem" dapat diartikan kemauan untuk melakukan sesuatu berdasarkan kemampuan yang dimiliki. Seperti yang diungkapkan oleh An dalam kutipan berikut ini, "wong iso durung tentu gelem, ning nek ora iso tapi gelem...bedha perkarane". Dapat dimaknakan bahwa seseorang yang memiliki kemampuan belum tentu mau melakukan, dan akan mendatangkan kesia-siaan. Namun sebaliknya orang yang tidak bisa atau tidak memiliki kemampuan tapi mau melakukan atau setidaknya berusaha untuk melakukan tentu akan mencapai hasil yang lebih baik. Dengan kata lain, pencapaian ditentukan pada kemauan individu itu untuk melaksanakan. Selama ada kemauan maka yang awalnya tidak dapat dilakukan akan dapat dikerjakan karena ada kemauan untuk belajar, seperti yang terwakili dalam pernyataan An berikut ini, "yen gelem...mesti iso ngelakoni. Yen ning ora gelem... senajan bener duwe kemampuan utawa pakulinan nanging yen ora gelem ngelakoni yo...mesti ora kelakon”.

Adapun konsep "Iso lan Gelem" yang diuraikan oleh An terbagi dalam 7 dimensi, seperti yang diuraikan dalam tabel berikut ini : 
Table 1. Konsep "Biso lan Gelem”

\begin{tabular}{|c|c|c|c|}
\hline & 7 dimensi & Biso & Gelem \\
\hline \multirow[t]{3}{*}{1} & $\begin{array}{l}\text { Moco } \\
\text { (membaca) }\end{array}$ & $\begin{array}{l}\text { Iso moco opo wae } \\
\text { Moco kahanan - moco tanpo tulisan } \\
\text { (membaca keadaan, situasi, ekspresi } \\
\text { emosi, mimik muka) } \\
\text { Membaca dalam arti lahiriah: } \\
\text { menambah wawasan dan pengalaman } \\
\text { Membaca dalam arti batiniah: } \\
\text { mampu membaca suasana, } \\
\text { temperamen, gestur dan mimik muka }\end{array}$ & $\begin{array}{l}\text { Gelem moco } \\
\text { Memiliki kemauan untuk melakukan amatan } \\
\text { dan membaca segala sesuatu, baik bersifat } \\
\text { lahiriah maupun batiniah. }\end{array}$ \\
\hline & $\begin{array}{l}\text { Ngrungokk } \\
\boldsymbol{e} \\
\text { (mendengar } \\
\text {-kan) }\end{array}$ & $\begin{array}{l}\text { Iso ngrungokke } \\
\text { Kemampuan untuk mendengarkan } \\
\text { secara aktif. }\end{array}$ & $\begin{array}{l}\text { Gelem ngrungokke } \\
\text { Kemauan untuk mendengarkan secara aktif }\end{array}$ \\
\hline & & $\begin{array}{l}\text { Biso moco lan ngrungokke } \\
\text { Kemampuan mengamati baik secara } \\
\text { visual ataupun auditori. }\end{array}$ & $\begin{array}{l}\text { Gelem moco lan Gelem ngrungokke } \\
\text { Mau melakukan pengamatan dan } \\
\text { mendengarkan secara aktif. }\end{array}$ \\
\hline 2 & $\begin{array}{l}\text { Ngguyu } \\
\text { (tertawa) }\end{array}$ & $\begin{array}{l}\text { Iso ngguyu } \\
\text { Mampu memberikan respon yang } \\
\text { menceriakan suasana ataupun pada } \\
\text { lawan bicara (dapat merespon } \\
\text { sesuatu yang lucu) }\end{array}$ & $\begin{array}{l}\text { Gelem ngguyu } \\
\text { Mau menunjukkan respon secara nyata } \\
\text { terhadap sesuatu yang lucu (suasana atau } \\
\text { pasangan) dengan bersikap ceria, terbuka. } \\
\text { Memberikan tanggapan yang tulus sehingga } \\
\text { suasana menjadi lebih akrab. }\end{array}$ \\
\hline 3 & $\begin{array}{l}\text { Mikir } \\
\text { (berpikir) }\end{array}$ & $\begin{array}{l}\text { Iso mikir } \\
\text { Mampu berpikir terutama dalam } \\
\text { menyikapi segala sesuatu yang } \\
\text { terjadi di dalam rumah tangga. }\end{array}$ & $\begin{array}{l}\text { Gelem mikir } \\
\text { Mau memberikan respon secara dinamis, } \\
\text { punya inisiatif, dan mampu memberikan } \\
\text { kontribusi, menunjukkan keterlibatan secara } \\
\text { aktif dan ikut memberikan alternatif solusi. } \\
\text { Mau peduli dan tanggap terhadap keadaan } \\
\text { keluarga. }\end{array}$ \\
\hline 4 & $\begin{array}{l}\text { Ndungo } \\
\text { (berdoa) }\end{array}$ & $\begin{array}{l}\text { Iso ndungo } \\
\text { Mampu mensyukuri anugrah Tuhan. } \\
\text { Berarti berdoa untuk diri sendiri dan } \\
\text { keluarga }\end{array}$ & $\begin{array}{l}\text { Gelem ndungokake } \\
\text { Wujud syukur atas karunia yang diterima } \\
\text { diwujudkan dalam perilaku mendoakan } \\
\text { sesama }\end{array}$ \\
\hline 5 & $\begin{array}{l}\text { Ngibadah } \\
\text { (beribadah) }\end{array}$ & $\begin{array}{l}\text { Iso Ibadah } \\
\text { Terkait dengan ritual Ibadah } \\
\text { Mengenal dan mampu melakukan } \\
\text { ibadah }\end{array}$ & $\begin{array}{l}\text { Gelem Ibadah } \\
\text { Mau melakukan ibadah secara konkrit, dapat } \\
\text { membentuk suasana kerohaniaan di rumah. }\end{array}$ \\
\hline 6 & $\begin{array}{l}\text { Gojek } \\
\text { (bercanda- } \\
\text { humor) }\end{array}$ & $\begin{array}{l}\text { Iso Gojeg } \\
\text { Dapat bercanda (diajak bercanda } \\
\text { maupun mengajak bercanda). } \\
\text { Dapat mencairkan suasana sehingga } \\
\text { suasan keluarga menjadi lebih } \\
\text { terbuka, lebih akrab, ketegangan } \\
\text { menurun. }\end{array}$ & $\begin{array}{l}\text { Gelem gojeg } \\
\text { Mau berupaya memberikan relaksasi untuk } \\
\text { meredakan ketegangan keluarga } \\
\text { (menciptakan atau menggunakan humor } \\
\text { untuk mencairkan suasana, menenangkan } \\
\text { siatuasi yang tegang) - dengan tujuan untuk } \\
\text { mencapai keseimbangan. }\end{array}$ \\
\hline 7 & $\begin{array}{l}\text { Dono/wewe } \\
\boldsymbol{h} \\
\text { (memberi) }\end{array}$ & $\begin{array}{l}\text { Iso dono } \\
\text { Memiliki kemampuan untuk } \\
\text { berderma, berbagi bagi orang lain, } \\
\text { baik dalam bentuk perhatian/empati } \\
\text { (roso), tenaga dan waktu serta harta }\end{array}$ & $\begin{array}{l}\text { Gelem dono } \\
\text { Meskipun mampu belum tentu seseorang mau } \\
\text { berderma, sehingga harta atau kemampuan } \\
\text { yang dimiliki tidak menjadi berkat atau } \\
\text { manfaat bagi orang lain. }\end{array}$ \\
\hline
\end{tabular}




\section{Pembahasan}

Meminjam kerangka teori Family Strengths Framework (DeFrain \& Asay, 2012), maka dimensidimensi dalam konsep "Iso lan Gelem" tersebut dapat dibahas sebagai berikut:

(a) Pada dimensi Moco (Iso moco opo wae; Gelem moco) - Ngrungoke(Iso ngrungoke; Gelem ngrungoke) yang dimaknakan oleh partisipan sebagai kemauan dan kemampuan untuk mendengarkan secara aktif. Dalam berbicara atau berkomunikasi dengan orang lain tidak cukup hanya mendengar saja tanpa disertai empati. Dalam berkomunikasi perlu adanya kemauan untuk memahami ekspresi lawan bicara, maupun isi pembicaraan dari sudut pandang lawan bicara. Bila ditelaah dalam dengan kerangka teori Family Strengths Framework, maka dapat disepadankan dengan dimensi komunikasi positif yang ditandai dengan perilaku saling berbagi perasaan, saling memberikan pujian, saling berkompromi dan terbuka terhadap ketidaksetujuan.

(b) Pada dimensi Ngguyu (Iso ngguyu; Gelem ngguyu) dan Gojek (Iso gojek; Gelem gojek), dimaknakan oleh partisipan sebagai kemauan dan kemampuan untuk memberikan respon atau menanggapi suatu kondisi secara ringan, penuh humor dan menyenangkan. Sehingga relasi yang terjadi antar anggota keluarga tidak diwarnai oleh ketengangan. Bila masing-masing anggota keluarga memiliki selera humor maka ketegangan yang muncul karena perbedaan pendapat ataupun konflik dapat diredakan. Dalam kerangka teori Family Strengths Framework, dimensi Ngguyu dan Gojek memiliki kesamaan makna dengan dimensi apresiasi dan afeksi. Salah satu indikator dalam dimensi apresiasi dan afeksi adalah hadirnya humor dalam keluarga dan mampu membawa kondisi yang dialami keluarga menjadi sesuatu yang menyenangkan.

(c) Pada dimensi Mikir (Iso mikir; Gelem mikir), partisipan memaknakan sebagai kemampuan dan kemauan untuk menggunakan olah pikirnya dalam menyikapi segala sesuatu yang dihadapi oleh keluarga. Secara aktif mau memberikan kontribusi baik dalam keterlibatan maupun alternatif solusi sebagai suatu penyelesaian masalah. Bila ditinjau dari Family Strengths Framework maka dimensi Mikir tersebut memberikan gambaran serupa dengan dimensi kemampuan untuk mengatasi stres dan krisis secara efektif, yang ditandai dengan indikator adanya kemampuan beradaptasi, melihat krisis sebagai tantangan dan kesempatan, bertumbuh dalam krisis, terbuka terhadap perubahan dan menjadi resilien.

(d) Pada dimensi Ndungo (Iso ndungo; Gelem ndungo) dan Ngibadah (Iso ibadah; Gelem Ibadah), partisipan memaknakan sebagai kemampuan dan kemauan untuk bersyukur pada Tuhan dalam bentuk doa dan sikap. Rasa syukur ini yang kemudian diwujudkan dalam sikap peduli pada sesama. Biasanya saat menghadapi masalah pelik keluarga, partisipan dan keluarga bersandar dan meminta pertolongan dari Tuhan melalui doa. Selain itu anggota keluarga juga harus rajin dan tekun beribadah sehingga dapat membangun suasana religius di rumah dan memiliki spiritualitas yang kuat. Selain 2 dimensi tersebut, terdapat dimensi yang ketiga yang juga memiliki keterkaitan makna dengan dimensi Ndungo dan Ngibadah, yaitu Dono/weweh (Iso dono; Gelem dono) yang dimaknai oleh partisipan sebagai kemampuan dan kemauan untuk berbagi dengan sesama, berderma, memberikan bantuan baik dalam bentuk perhatian, tenaga, waktu maupun materi. Bila ditinjau dari Family Strengths Framework maka dimensi tersebut memiliki makna yang selaras dengan dimensi kesejahteraan spiritual, yang memuat indikator harapan, keyakinan, pengorbanan, berbagi nilai etis dan kemanusiaan.

Sebagai tambahan, mengacu pada kutipan partisipan tentang definisi keluarga tangguh, tersirat adanya makna kemauan untuk saling menerima apa adanya terutama kekurangan yang dimiliki masing-masing anggota keluarga, kemauan untuk menghadapi bersama-sama baik masalah maupun perbedaan pendapat. Bila ditinjau dari Family Strengths Framework, maka makna tersebut memiliki 
kesepadanan dengan dimensi komitmen. Dimensi komitmen menunjukkan adanya rasa saling percaya, dapat saling diandalkan dan kesetiaan. Dengan demikian dapat ditarik suatu pemahaman bahwa partisipan juga menekankan pentingnya komitmen sebagai fondasi untuk membangun keluarga yang tangguh.

\section{KESIMPULAN DAN SARAN}

Dapat ditarik kesimpulan bahwa konsep "Iso lan Gelem" yang dikemukakan oleh partisipan memiliki kesepadanan makna dengan 5 dimensi dari Family Strengths Framework, yaitu: (a) komunikasi positif, (b) apresiasi dan afeksi, (c) kemampuan untuk mengatasi stres dan krisis secara efektif, (d) kesejahteraan Spiritual, dan (e) komitmen. Sedangkan 1 dimensi dalam Family Strengths Framework yang tidak ditemukan pada data dari partisipan adalah dimensi menikmati waktu bersama.

Berdasarkan hasil penelitian tersebut dapat disarankan beberapa hal, antara lain: (a) salah satu dimensi dalam Family Strengths Framework yang tidak muncul adalah menikmati waktu bersama. Oleh karena itu dapat disarankan untuk penelitian lanjutan untuk mengulas apakah dimensi tersebut memang tidak menjadi kekuatan keluarga pada etnis Jawa ataukah sebenarnya ada namun belum tergali, mengingat dalam penelitian ini hanya menggunakan kasus tunggal; (b) sebagai penelitian awal, temuan dalam penelitian ini telah memberikan wacana lain. Oleh karenanya perlu dilanjutkan dalam penelitian berikutnya dengan melibatkan subyek yang lebih banyak, agar masukan yang diperoleh lebih beragam; (c) terkait dengan metode pengumpulan data, dapat disarankan untuk menggunakan metode yang berbeda seperti menggunakan FGD (focus group disscussion). Diharapkan penggunaan FGD dapat membantu peneliti lebih fokus menemukan tema yang muncul; (d) selain itu dapat disarankan pula untuk melakukan penelitian kuantitatif dengan menggunakan alat ukur yang valid dan reliabel, baik alat ukur yang dibuat sendiri oleh peneliti atau modifikasi dari alat ukur yang sudah ada.

\section{Ucapan Terima Kasih (Acknowledgement)}

Kami ucapkan terima kasih kepada partisipan yang telah bersedia terlibat dalam penelitian ini. Tak lupa pula kami ucapkan terima kasih kepada Fakultas Psikologi yang telah memberikan ijin untuk melakukan penelitian ini.

\section{REFERENSI}

Ahmed, Z.S. (2005). Poverty, Family Stress \& Parenting. Retrieved January 15, 2011, from http://www.humiliationstudies.org/documents/AhmedPovertyFamilyStressParenting.pdf

Compton, W.C. (2005). An introduction to positive psychology. Belmont, CA: Thomas Wadsworth

Conoley, C.W., Conoley J.C. (2009). Positive Psychology and Family Therapy: Creative techniques and practical tools for guiding change and enhancing growth.

DeGenova, M.K., Stinnett, N., Stinnett, N. (2011). Intimate relationships, marriages \& families. New York, NY: Mc.GrawHil.

DeFrain, J., Asay S.M. (2012). Strong Families Around the World: Strengths-Based Research and Perspective. New York, NY: Routledge

Olson, D.H., \& DeFrain, J. (2006). Important notes about family strengths from Olson. Retrived January, 15, 2012, from www.fch.utah.edu/ herrin/olson.notes.rtf

Olson, D.H., \& DeFrain, J. (2006). Marriages \& Families: Intimacy, Diversity and Strengths $\left(5^{\text {th }}\right.$ ed). Boston: McGraw Hill. 
Rice, F.P. (1999). Intimate Relationships, Marriages \& Families (4 ${ }^{\text {th }}$ ed). Mountain View, CA: Mayfield Publishing.

Wheeler, T. (2008). Investigating the interrelationship among family measures of family strengths. (doctoral dissertation). Kansas State University, Manhattan, Kansas. Retrieved from http://search.proquest.com/docview/304548732/ previewPDF/1344795CD22321453B0/6 